\title{
Snake assemblage of Estação Ecológica de Santa Bárbara, SP: a Cerrado remnant in Southeastern Brazil
}

\author{
Cybele de Oliveira Araujo ${ }^{1,2,3}$, Décio Tadeu Corrêa Filho ${ }^{2}$ \& Ricardo Jannini Sawaya ${ }^{2}$ \\ ${ }^{1}$ Seção de Animais Silvestres, Instituto Florestal, \\ Rua do Horto, 931, Horto Florestal, CEP 02377-000, São Paulo, SP, Brazil \\ ${ }^{2}$ Laboratório de Ecologia e Evolução, Instituto Butantan, \\ Av. Dr. Vital Brazil, 1500, CEP 05503-900, São Paulo, SP, Brazil \\ ${ }^{3}$ Corresponding author: Cybele de Oliveira Araujo, e-mail: cyaraujo@usp.br
}

\begin{abstract}
ARAUJO, C.O., CORRÊA FILHO, D.T. \& SAWAYA, R.J. Snake assemblage of Estação Ecológica de Santa Bárbara, SP: a Cerrado remnant in Southeastern Brazil. Biota Neotrop. 10(2): http://www.biotaneotropica. org.br/v10n2/en/abstract?inventory+bn01410022010.
\end{abstract}

\begin{abstract}
Despite the great extension of the Cerrado and its importance for biodiversity conservation, there are still sampling gaps in this region that has shown conspicuous changes over the years due to the conversion of natural areas into pastures and plantations. Around $88.5 \%$ of the Cerrado areas in the State of the São Paulo were cleared in the last four decades and less than $0.81 \%$ of the original Cerrado vegetation remains as pristine habitats, although these areas once covered $14 \%$ of the state. We present the list of snakes that occur in the Estação Ecológica de Santa Bárbara, a remnant of Cerrado in the State of São Paulo, in addition to information on the abundance and distribution of species in the various habitats found at this location. The survey was conducted between October 2008 and March 2009 during six monthly field trips of five days each, totaling 30 sampling days. Surveys were conducted using incidental encounters (IE) and pitfall traps (PT). We recorded a total of 21 species belonging to 15 genera and six families. All species and individuals captured (18 species; 49 individuals) were found in open Cerrado formations. No individual was observed in the sampled forest habitats (cerradão and dry forest). Forested habitats occupy a relatively small portion of this protected area (12.6\%). However, the higher species richness in open habitats may not be a result of limited local coverage of forests. The higher richness in interfluvial open habitats has also been recorded in other Cerrado areas. This survey is an important contribution towards enhancing our knowledge about the snake assemblage in the highly threatened Cerrado of São Paulo State. Hence, these last protected remnants in the state that still house significant areas of open Cerrado formations, such as the Estação Ecológica de Santa Bárbara, although reduced, are extremely important for the conservation of reptiles in the State of São Paulo, in Southeastern Brazil, and in the Cerrado region.
\end{abstract}

Keywords: Squamata, snakes, Cerrado, conservation, Águas de Santa Bárbara, São Paulo, Brazil.

ARAUJO, C.O., CORRÊA FILHO, D.T. \& SAWAYA, R.J. Serpentes da Estação Ecológica de Santa Bárbara, SP: um remanescente de Cerrado do Sudeste do Brasil. Biota Neotrop. 10(2): http://www.biotaneotropica. org.br/v10n2/pt/abstract?inventory+bn01410022010.

Resumo: Apesar da grande extensão do Cerrado no território nacional e enorme importância para a conservação da biodiversidade, ainda existem lacunas amostrais neste domínio fitogeográfico, que vem sofrendo ao longo dos anos modificações acentuadas devido à conversão de suas áreas naturais em pastagens e monoculturas. A drástica redução das áreas de Cerrado no Estado de São Paulo nas últimas quatro décadas foi da ordem 88,5\%, restando menos de $0,81 \%$ da área original do Cerrado paulista, que originalmente cobria $14 \%$ da área do estado. Este estudo apresenta a lista de serpentes que ocorrem na Estação Ecológica de Santa Bárbara, um remanescente de Cerrado no Estado de São Paulo, com informações sobre a abundância e distribuição das espécies em vários hábitats presentes nesta localidade. O inventário foi realizado entre outubro de 2008 e março de 2009, em seis etapas de campo mensais de cinco dias cada, totalizando 30 dias de amostragens que foram realizadas por meio de encontros ocasionais (IE) e armadilhas de interceptação e queda (PT). Foram registradas no total 21 espécies pertencentes a 15 gêneros e seis famílias. Todas as espécies e indivíduos capturados (18 espécies; 49 indivíduos) foram encontrados em formações abertas de Cerrado. Não foi observado nenhum indivíduo nas formações florestais amostradas (cerradão e mata seca). Os hábitats florestais ocupam uma pequena porção relativa desta área protegida (12.6\%). No entanto, a maior riqueza de espécies encontrada nos ambientes abertos não pode ser considerada como resultado da limitada cobertura florestal desta localidade. A maior riqueza de espécies em hábitats abertos de interflúvio já foi registrada em outras áreas de Cerrado do país. Este inventário é uma importante contribuição para a ampliação do conhecimento desta taxocenose no ameaçado Cerrado paulista. Nesse sentido, apesar de reduzidos, esses últimos remanescentes protegidos por lei no estado que ainda abrigam áreas significativas com formações abertas de Cerrado, como a Estação Ecológica de Santa Bárbara, são de extrema importância não só para a conservação dos répteis no Estado de São Paulo, mas também para o Sudeste do Brasil e domínio do Cerrado.

Palavras-chave: Squamata, serpentes, Cerrado, conservação, Águas de Santa Bárbara, São Paulo, Brasil. 


\section{Introduction}

Brazil is one of the two richest countries in the world in terms of biodiversity, harboring two of the 34 global biodiversity hotspots for conservation priorities: the Atlantic Forest and the Cerrado (Mittermeier et al. 2004). The Cerrado region is one of the few global hotspots dominated by savanna-type vegetation. The relief include plateaus, the depressions and the plains with several phytophysiognomies (e.g., dry forest, cerradão, cerrado denso, cerrado típico, cerrado ralo, campo sujo, campo limpo, campo rupestre) (Ab'Sáber 2005, Fonseca et al. 1999, 2004, Ribeiro \& Walter 2008). The heterogeneity of this region is reflected in its biota that was once considered poor, but has now become recognized as one of the formations with highest degree of endemism and human disturbance in the world (Colli et al. 2002, IBGE 2004).

The Cerrado region occupied originally an area of 2 million $\mathrm{km}^{2}(23 \%$ of the Brazilian territory), being currently extremely threatened by agriculture and cattle-farming, responsible for most of the loss of its natural vegetation (Ratter et al. 1997, Klink \& Machado 2005, Durigan \& Ratter 2006, Durigan et al. 2007). Despite its large extension and huge importance for biodiversity conservation (Myers et al. 2000), only $2.2 \%$ of region are covered by strictly protected areas (Strict Nature Reserve, Wilderness Area, National Park, and Natural Monument) (Klink \& Machado 2005, IUCN 2009). Recent studies have estimated from satellite images that almost $55 \%$ of the Cerrado has been destroyed and if there is no reversal in the occupancy rate, as from 2030 there will no longer be any natural areas except those inside conservation units (Machado et al. 2004).

By far, the most severely impacted region of the Cerrado is its Southernmost portion, including the São Paulo State. The reduction of the Cerrado in the State of São Paulo during the last four decades has been of $88 \%$ of the original area, replaced by sugar cane, cash crops, citrus, pasture and Pinus or Eucalyptus plantations (Kronka et al. 2005). An intense fragmentation was observed in the Cerrado of São Paulo, and currently a total of 7.505 fragments are recorded in this state, of which, $71 \%$ are extremely small (less than 20 ha), $0.6 \%$ reach approximately 400 ha and only $0.1 \%$ reach 10,000 ha (Kronka et al. 2005). Presently, less than $0.8 \%$ of the original extent of Cerrado in São Paulo State (14\%) remains as original habitats (São Paulo 1997, Kronka et al. 2005). Moreover, only $0.5 \%$ of this region is protected in conservation units in the state and all these scattered fragments are threatened by factors such as isolation, artificial fire regimes and invasion by exotic plant species (Durigan et al. 2004, 2007).

Among the various plant formations of the Cerrado, the more open phytophysiognomies such as grassland and savanna-type formations, show a greater diversity of herpetofauna (e.g., Dalmolin 2000, Sawaya 2004, Brasileiro et al. 2005, Nogueira et al. 2009). These formations are precisely those which are most likely to disappear in the state and in the Brazilian territory. Durigan et al. (2003) analyzed the vegetation cover of 86 fragments of Cerrado considered priorities for conservation in the state, and shows that cerradão is the dominant vegetation (70\%), followed by riverine forest (60\%) and the cerrado/ dry forest ecotone (37\%). Typical cerrado was found in $27 \%$ of the fragments, and campo sujo (3.5\%) and cerrado ralo (8\%) were rarely found. Recent studies based on data from satellite images, aerial photographs and field surveys have shown that the open Cerrado vegetation has decreased drastically over the past decades, from $16 \%$ (1962) to only $0.6 \%$ (1992) of the area occupied by Cerrado in the state (Durigan \& Ratter 2006). Historically, the open Cerrado areas in the Western São Paulo State have been used for extensive cattle-raising on native vegetation which was later replaced by
African grasses, causing loss of local plant diversity (Durigan \& Ratter 2006).

However, although the open formations are quite endangered in the state, there are still some fragments that harbor populations of relatively rare snakes, such as Philodryas agassizii (Jan, 1863), Xenodon nattereri (Steindachner, 1867) and Rhinocerophis itapetiningae (Boulenger, 1907), regarded as specialized in the use of the habitat and restricted to grassland formations (Sawaya et al. 2008, Marques et al. 2006).

To date, 141 species of snakes are known for the State of São Paulo (Rossa-Feres et al. 2008), representing 38\% of the snake richness in Brazil (Bérnils 2010). For the most part, studies conducted in the State of São Paulo that include information on species composition, ecology and natural history of snakes have been conducted in localities of the Altlantic Plateau, Serra do Mar, and offshore islands (e.g., Sazima \& Haddad 1992, Marques 1998, Sazima 2001, Hartmann 2005, Dixo \& Verdade 2006, Cicchi et al. 2007, Sena 2007, Centeno et al. 2008, Domenico 2008, Rocha et al. 2008, Condez et al. 2009).

Studies on Squamate reptile fauna in Cerrado and seasonal forests formations of the State of São Paulo are still scarce. Vanzolini (1948) provides general information about the richness, abundance and habitat use of snakes and lizards from Cerrado in the municipality of Pirassununga. Sazima \& Manzani (1995) studied the ecology and natural history of snakes in a locality of seasonal semi-deciduous forest (Mata de Santa Genebra). Only three studies have been performed in Cerrado conservation units of São Paulo State: Dalmolin (2000) studied the ecology and natural history of the snake community at Estação Ecológica de Jataí and immediate vicinities, Sawaya (2004) conducted a study on the ecology, natural history and diversity of snakes in the region of the Estação Ecológica de Itirapina and Nogueira et al. (2009) conducted a study comparing lizards faunas across ten localities in the Cerrado region, including the Estação Ecológica de Santa Bárbara.

Detailed studies about the biology, distribution and conservation of snakes were conducted at some regions of the Brazil (e.g., Vitt \& Vangilder 1983, Strüssmann \& Sazima 1993, Bernarde \& Abe 2006, Sawaya et al. 2008, Carvalho \& Nogueira 1998, Strüssmann 2000, França \& Araújo 2006, Colli et al. 2002, Costa et al. 2007). However, there are still considerable sampling gaps even within regions considered worldwide priorities for conservation because of the high degree of endemism and human disturbance, such as the Cerrado (Myers et al. 2000). Accordingly, inventories and monitoring of wildlife may fill important gaps about the biology of these species and the knowledge found can be used as a sound basis for developing effective management and conservation measures.

Information about habitat use of a given species is scarce in inventories on snake assemblages. Thus, the objective of this study was to provide information on the composition and habitat use of snakes in a protected area of Cerrado in São Paulo State and generate support for the management of this ecosystem and consequently the conservation of these species.

\section{Material and Methods}

\section{Study area}

The Estação Ecológica de Santa Bárbara (22 46' 30" $22^{\circ} 50^{\prime} 30^{\prime \prime} \mathrm{S}$ and $49^{\circ} 10^{\prime} 30^{\prime \prime}-49^{\circ} 15^{\prime} 30^{\prime \prime} \mathrm{W}$; $600-680 \mathrm{~m}$ in altitude) is located in the municipality of Águas de Santa Barbara, State of São Paulo, Brazil, and has a total area of 3223 ha (Figure 1). The climate is type Cwa of Köppen's classification (Köppen 1948), with average temperatures between 23 and $24{ }^{\circ} \mathrm{C}$ during the hottest month (January), and average temperatures of around 

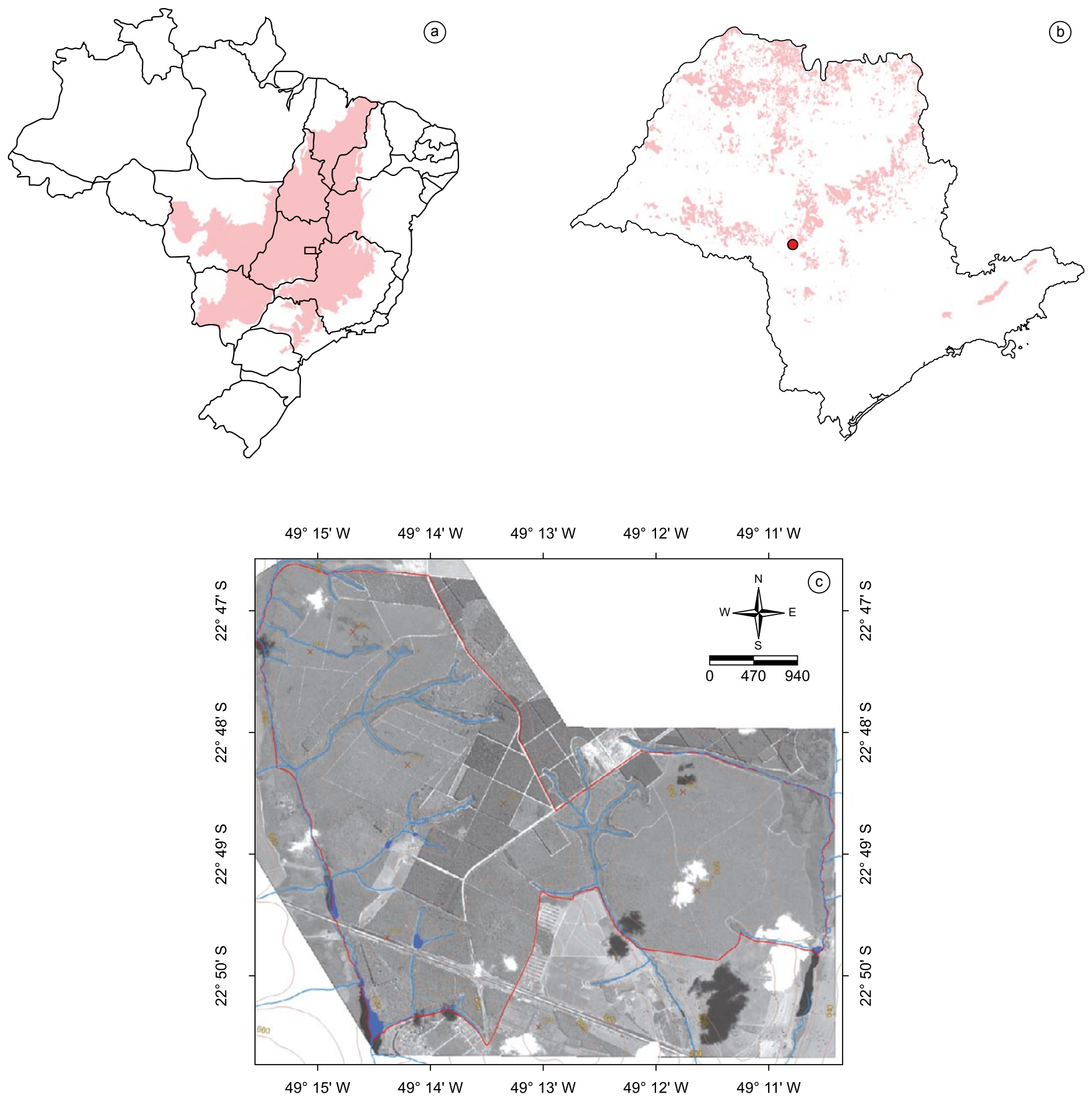

Figure 1. a) Original cover of the Cerrado in Brazil; b) original distribution of the Cerrado in the State of São Paulo and position of the Estação Ecológica de Santa Bárbara in the state; and c) aerial photograph of this protect area.

$16{ }^{\circ} \mathrm{C}$ in the coldest month (July). The average annual rainfall is between 1.100 and $1.300 \mathrm{~mm}$, with dry and rainy seasons (Setzer 1966). The vegetation in this ecological station consists largely of Cerrado, being composed predominantly by grassland and savannatype formations, such as cerrado típico (34.4\%), cerrado denso (10.2\%), cerrado ralo (7\%) and campo limpo úmido (6.5\%). The natural forest physiognomies found at the site are cerradão (11.9\%), gallery forest $(4 \%)$, and dry forest $(0.7 \%)$ (Durigan et al. in press) (Figure 2). The phytophysiognomies of this locality were classified sensu Ribeiro and Walter (2008), in which cerrado sensu stricto is subdivided into cerrado denso (predominantly arboreal vegetation with 50 to $70 \%$ canopy cover and average height between 5 and $8 \mathrm{~m}$ ), cerrado típico (predominantly arboreal-shrub vegetation with 20 to $50 \%$ arboreal cover and average height between 3 and $6 \mathrm{~m}$ ) and cerrado ralo (arboreal-shrub vegetation with 5 to $20 \%$ arboreal cover and average height between 2 and $3 \mathrm{~m}$ ). The campo limpo that occurs in areas where the groundwater table is close to the surface is called campo limpo úmido (Ribeiro \& Walter 2008). More detailed definitions about Cerrado phytophysiognomies can 
Araujo, C.O. et al.

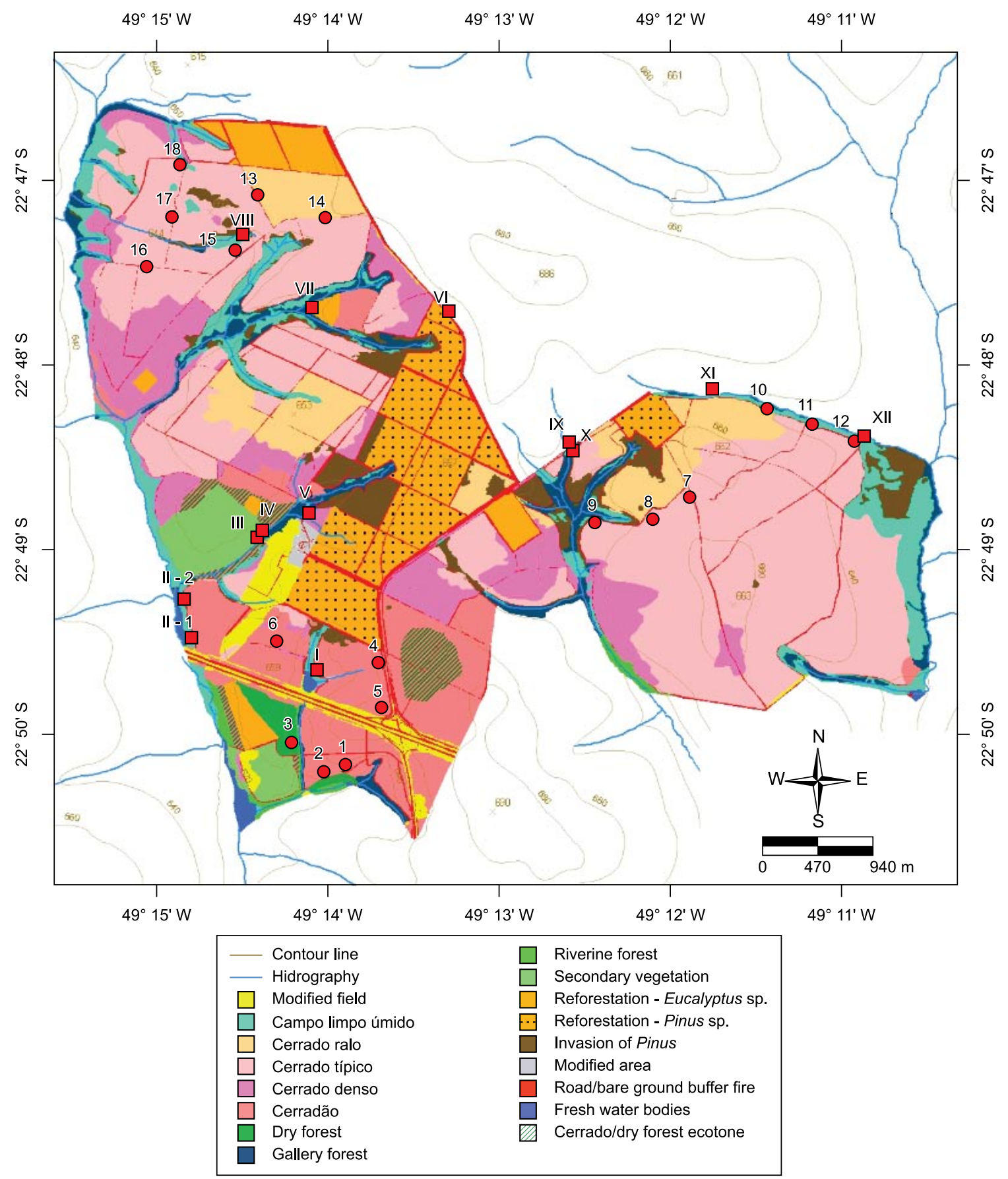

Figure 2. Phytophysiognomies of the Estação Ecológica de Santa Bárbara, State of São Paulo, Brazil and sampled areas (red dots = rows of pitfall traps; red squares $=$ aquatic habitats) (Source: Durigan et al. in press).

be found in Oliveira-Filho and Ratter (2002), Durigan et al. (2003), and Ribeiro and Walter (2008).

\section{Data collection}

The snake survey was conducted between October 2008 and March 2009 during six monthly field trips of five days each, totaling 30 sampling days.

For sampling the snakes we used pitfall traps with drift-fences (Corn 1994, Cechin \& Martins 2000). With the specific objective of characterizing the distribution of snake species in the different Cerrado formations of the Estação Ecológica de Santa Bárbara, rows of four $60 \mathrm{~L}$ plastic buckets were set up in eighteen selected areas (four physiognomies) (Figure 3 ) totaling 72 traps (sampling effort $=2.160$ buckets/day). The geographical coordinates of the selected areas for installing the traps were obtained by GPS (Global Positioning System) (Table 1).

The method of incidental encounters (IE) was also used for recording the snake species found, alive or dead, whilst walking in the sampling areas and vicinity. Although the sampling effort is not considered, the incidental encounters method is useful for obtaining animals for records of species richness, more comprehensive lists and data of species behavior (e.g., use of habitat, diet and reproductive activity) (Martins 1994, Sawaya 2004). 

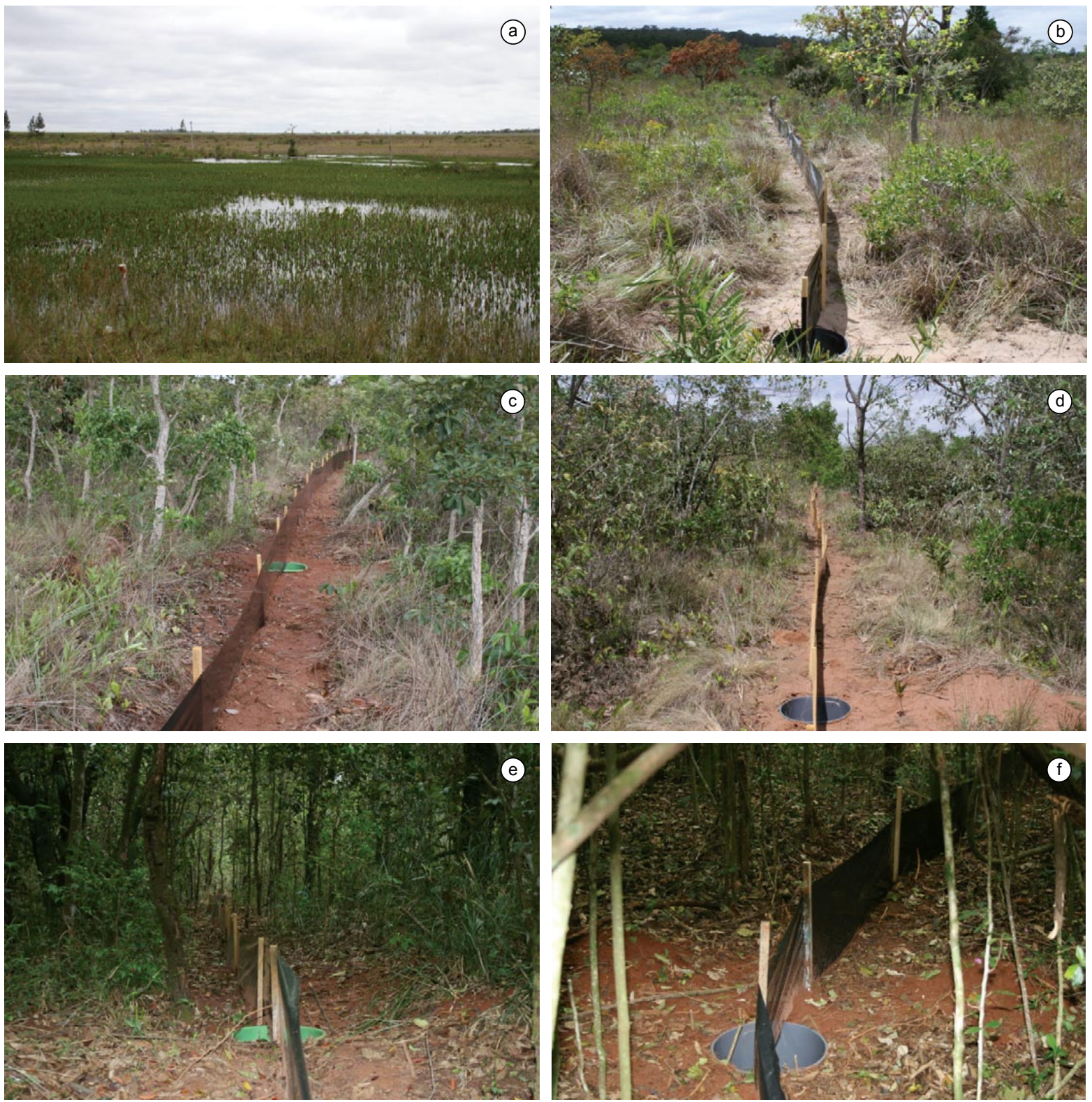

Figure 3. Rows of pitfall traps installed in the Cerrado phytophysiognomies sampled at the Estação Ecológica de Santa Bárbara, State of São Paulo, Brazil and aquatic habitat. $\mathrm{a}=$ campo limpo úmido; $\mathrm{b}=$ cerrado ralo (row 14); $\mathrm{c}=$ cerrado típico/cerrado ralo transition (row 10); $\mathrm{d}=$ cerrado típico (row 15); $\mathrm{e}=$ cerradão (row 5); $\mathrm{f}=$ dry forest (row 3).

The sampling efficiency was evaluated through a rarefaction curve (Gotelli \& Colwell 2001) built with presence and absence data of species observed in the locality during the 30 sampling days (one sample $=$ one day). The species richness was estimated by first order Jacknife (Jacknife 1). The richness estimator was selected by visual comparisons of the performance of six estimators: Chao 1 and 2; Jacknife 1 and 2; ACE and ICE (cf. Moraes et al. 2007). The curves were generated in EstimateS v. 8.2.0 with 10.000 randomizations (Colwell 2009) (Figure 4).

In addition to field samples, previous records to the municipality of Águas de Santa Bárbara were included in species list. We consulted herpetological collections in the State of São Paulo, namely Coleção Herpetológica do Instituto Butantan (IBSP) and Coleção Herpetológica do Museu de Zoologia da Universidade de São Paulo (MZUSP). Specimens collected (collection permits IBAMA/RAN
10423-1 and 13706-2) were deposited in the IBSP collection (see Appendix 1).

\section{Results and Discussion}

Twenty one species of snakes were recorded for the Estação Ecológica de Santa Bárbara and region, belonging to six families: Leptotyphlopidae, Boidae, Colubridae, Dipsadidae, Elapidae and Viperidae (Table 2, Figure 5). We captured 18 species in the field, and added to the records another three species, obtained from the Coleção Herpetológica do Instituto Butantan: Liophis reginae $(\mathrm{N}=1)$, Philodryas livida $(\mathrm{N}=1)$, and Micrurus frontalis $(\mathrm{N}=1)$. Besides these three species, the IBSP collection had a single record for Taeniophallus occipitalis, also captured during our field sampling. The MZUSP collection had only three records of snakes 
Araujo, C.O. et al.

Table 1. Rows of pitfall traps installed at the Estação Ecológica de Santa Bárbara, State of São Paulo, Brazil.

\begin{tabular}{|c|c|c|c|}
\hline Row number & Phytophysiognomy & Habitat type & Geographic coordenate \\
\hline 1 & cerradão & forest & $22^{\circ} 50^{\prime} 10,8^{\prime \prime} \mathrm{S}$ and $49^{\circ} 13^{\prime} 56,1^{\prime \prime} \mathrm{W}$ \\
\hline 2 & cerradão & forest & $22^{\circ} 50^{\prime} 12,8^{\prime \prime} \mathrm{S}$ and $49^{\circ} 14^{\prime} 03,9^{\prime \prime} \mathrm{W}$ \\
\hline 3 & dry forest & forest & $22^{\circ} 50^{\prime} 03,6^{\prime \prime} \mathrm{S}$ and $49^{\circ} 14^{\prime} 15^{\prime \prime} \mathrm{W}$ \\
\hline 4 & cerradão & forest & $22^{\circ} 49^{\prime} 37,5^{\prime \prime} \mathrm{S}$ and $49^{\circ} 13^{\prime} 45,1^{\prime \prime} \mathrm{W}$ \\
\hline 5 & cerradão & forest & $22^{\circ} 49^{\prime} 51,9^{\prime \prime} \mathrm{S}$ and $49^{\circ} 13^{\prime} 43,8^{\prime \prime} \mathrm{W}$ \\
\hline 6 & cerradão & forest & $22^{\circ} 49^{\prime} 30,8^{\prime \prime} \mathrm{S}$ and $49^{\circ} 14^{\prime} 20,6^{\prime \prime} \mathrm{W}$ \\
\hline 7 & cerrado típico & open & $22^{\circ} 48^{\prime} 42^{\prime \prime} \mathrm{S}$ and $49^{\circ} 11^{\prime} 56,9^{\prime \prime} \mathrm{W}$ \\
\hline 8 & cerrado típico & open & $22^{\circ} 48^{\prime} 49,9^{\prime \prime} \mathrm{S}$ and $49^{\circ} 12^{\prime} 09,5^{\prime \prime} \mathrm{W}$ \\
\hline 9 & cerrado típico & open & $22^{\circ} 48^{\prime} 50,9^{\prime \prime} \mathrm{S}$ and $49^{\circ} 12^{\prime} 29,8^{\prime \prime} \mathrm{W}$ \\
\hline 10 & cerrado típico/cerrado ralo & open & $22^{\circ} 48^{\prime} 13,4^{\prime \prime} \mathrm{S}$ and $49^{\circ} 11^{\prime} 30,2^{\prime \prime} \mathrm{W}$ \\
\hline 11 & cerrado típico & open & $22^{\circ} 48^{\prime} 18,4^{\prime \prime} \mathrm{S}$ and $49^{\circ} 11^{\prime} 14,2^{\prime \prime} \mathrm{W}$ \\
\hline 12 & cerrado típico & open & $22^{\circ} 48^{\prime} 23,4^{\prime \prime} \mathrm{S}$ and $49^{\circ} 10^{\prime} 59^{\prime \prime} \mathrm{W}$ \\
\hline 13 & cerrado ralo & open & $22^{\circ} 47^{\prime} 06,1^{\prime \prime} \mathrm{S}$ and $49^{\circ} 14^{\prime} 29,3^{\prime \prime} \mathrm{W}$ \\
\hline 14 & cerrado ralo & open & $22^{\circ} 47^{\prime} 13,2^{\prime \prime} \mathrm{S}$ and $49^{\circ} 14^{\prime} 05,5^{\prime \prime} \mathrm{W}$ \\
\hline 15 & cerrado típico & open & $22^{\circ} 47^{\prime} 24,2^{\prime \prime} \mathrm{S}$ and $49^{\circ} 14^{\prime} 36,7^{\prime \prime} \mathrm{W}$ \\
\hline 16 & cerrado típico & open & $22^{\circ} 47^{\prime} 29,6^{\prime \prime} \mathrm{S}$ and $49^{\circ} 15^{\prime} 07,5^{\prime \prime} \mathrm{W}$ \\
\hline 17 & cerrado típico & open & $22^{\circ} 47^{\prime} 13,5^{\prime \prime} \mathrm{S}$ and $49^{\circ} 14^{\prime} 59,3^{\prime \prime} \mathrm{W}$ \\
\hline 18 & cerrado típico & open & $22^{\circ} 46^{\prime} 56,5^{\prime \prime} \mathrm{S}$ and $49^{\circ} 14^{\prime} 56,2^{\prime \prime} \mathrm{W}$ \\
\hline
\end{tabular}

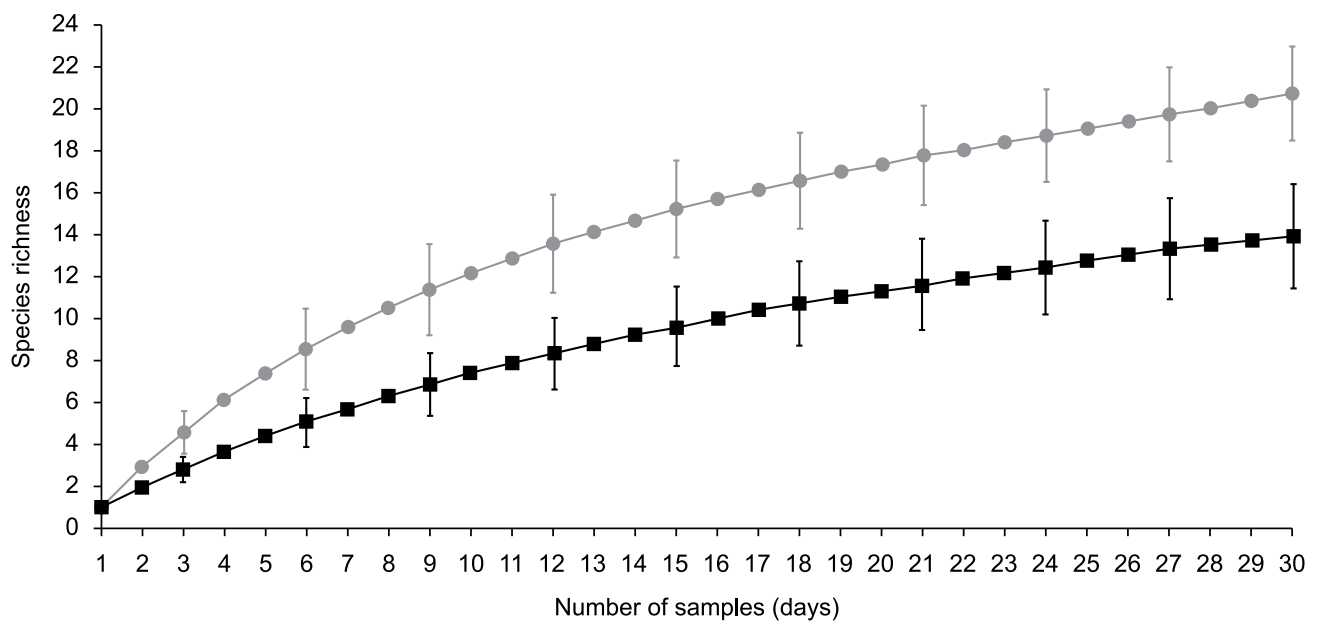

Figure 4. Rarefaction curve representing observed species richness (black line) and estimated richness curve generated by the estimator Jacknife 1 (gray line) to 30 sampled days with pitfall traps (October 2008 to March 2009) at the Estação Ecológica de Santa Bárbara. Vertical bars correspond to standard deviations of observed species richness and estimated richness. Curves were created by means of 10000 randomizations (Colwell 2009).

for the reserve: Atractus pantostictus, Sibynomorphus mikani and Tricheilostoma koppesi which were also found in our survey (Table 2). Such few records (seven species and seven individuals) for the Estação Ecológica de Santa Bárbara and region in two representative herpetological collections of the state emphasizes the need for inventories that will fill the gaps in our knowledge about the herpetofauna that inhabit many areas of the State of São Paulo.

We captured 14 species of snakes $(\mathrm{N}=41)$ in pitfall traps, four species $(N=4)$ were sampled exclusively through the incidental encounter method and three species $(\mathrm{N}=4)$ were captured through both methods (Table 2). All sampled individuals $(\mathrm{N}=49)$ were found in open Cerrado formations (cerrado ralo and cerrado típico), i.e. we did not find any species in the forest formations (cerradão and dry forest). Thus, we conclude that, in this ecological station, both the richness and the abundance of snake species in the open Cerrado formations are much higher than that of the forest formations. Despite the low representation of forest physiognomies in this protected area $(12.6 \%)$, the data suggest that the open Cerrado formations are the preferred habitat of the sampled snakes. Other studies comparing the richness of snakes (e.g., Dalmolin 2000, Sawaya 2004), lizards (e.g. Nogueira et al. 2009) and amphibians (e.g. Brasileiro et al. 2005) between open and forest formations in other Cerrado areas obtained similar results.

The rarefaction curve of the species richness captured by the pitfall traps during 30 sampling days (14 species) did not present tendency to stabilization, indicating that a higher number of species could be captured through this method if sampling effort was increased (Figure 4). Apart from the limited sampling period, some species are 
Table 2. Composition, number of individuals captured (N), percentage of the total number of individuals (\%), and capture site of the snake species sampled at Estação Ecológica de Santa Bárbara, State of São Paulo through pitfall trap (rows) and incidental encounters (IE) as well as secondary date from herpetological collections of the Instituto Butantan (IBSP) and Museu de Zoologia da Universidade de São Paulo (MZUSP).

\begin{tabular}{|c|c|c|c|}
\hline Family/Species & $\mathbf{N}$ & $\%$ & Site (row number) \\
\hline \multicolumn{4}{|l|}{ Leptotyphlopidae } \\
\hline Tricheilostoma koppesi ${ }^{1}$ (Amaral, 1955) & 3 & 5.4 & $(7 ; 10)$ \\
\hline \multicolumn{4}{|l|}{ Boidae } \\
\hline Boa constrictor Linnaeus, 1758 & 1 & 1.8 & IE \\
\hline \multicolumn{4}{|l|}{ Colubridae } \\
\hline Tantilla melanocephala (Linnaeus, 1758) & 15 & 26.8 & $(7 ; 8 ; 9 ; 10 ; 11 ; 13 ; 14 ; 15 ; 17)$ \\
\hline \multicolumn{4}{|l|}{ Dipsadidae } \\
\hline Atractus pantostictus ${ }^{1}$ Fernandes \& Puorto, 1993 & 7 & 12.5 & $\mathrm{IE} ;(11 ; 12)$ \\
\hline Liophis almadensis (Wagler, 1824) & 3 & 5.4 & $(10 ; 11 ; 16)$ \\
\hline Liophis poecilogyrus (Wied, 1825) & 1 & 1.8 & (13) \\
\hline Liophis reginae $^{2}$ (Linnaeus, 1758) & 1 & 1.8 & - \\
\hline Oxyrhopus guibei Hoge \& Romano, 1978 & 4 & 7.1 & IE; $(8 ; 10 ; 12)$ \\
\hline Oxyrhopus rhombifer Duméril, Bibron \& Duméril, 1854 & 1 & 1.8 & (13) \\
\hline Phalotris mertensi (Hoge, 1955) & 1 & 1.8 & IE \\
\hline Philodryas agassizii (Jan, 1863) & 1 & 1.8 & (14) \\
\hline Philodryas livida ${ }^{2}$ (Amaral, 1923) & 1 & 1.8 & - \\
\hline Philodryas patagoniensis (Girard, 1858) & 1 & 1.8 & $(18)$ \\
\hline Sibynomorphus mikanii ${ }^{1}$ (Schlegel, 1837) & 2 & 3.6 & IE \\
\hline Taeniophallus occipitalis ${ }^{3}$ (Jan, 1863) & 5 & 8.9 & $(9 ; 12 ; 15 ; 17)$ \\
\hline Thamnodynastes hypoconia (Cope, 1860) & 3 & 5.4 & IE; (13) \\
\hline Xenodon nattereri (Steindachner, 1867) & 1 & 1.8 & $(11)$ \\
\hline \multicolumn{4}{|l|}{ Elapidae } \\
\hline Micrurus frontalis ${ }^{2}$ (Duméril, Bibron \& Duméril, 1854) & 1 & 1.8 & - \\
\hline \multicolumn{4}{|l|}{ Viperidae } \\
\hline Bothropoides pauloensis (Amaral, 1925) & 1 & 1,8 & (8) \\
\hline Bothrops moojeni Hoge, 1966 & 2 & 3,6 & $(9 ; 10)$ \\
\hline Caudisona durissa (Linnaeus, 1758) & 1 & 1,8 & IE \\
\hline
\end{tabular}

${ }^{1}$ species recorded in the field and in the MZUSP collection; ${ }^{2}$ species recorded only in the IBSP collection; and ${ }^{3}$ species recorded in the field and in the IBSP collection.

not adequately sampled through pitfall traps (e.g. arboreal species). Snakes are relatively hard to sample and the combination of different sampling methods for this group is always necessary by the limitation inherent to each method (Sawaya 2004). The total species richness found in this locality, also considering the species recorded through incidental encounters and collection records (21 species) is similar to the estimated richness through pitfall traps (Jacknife $1=20.8$ ). However, the rarefaction curve of Jacknife estimator also did not show any tendency to stability (Figure 4), indicating a higher number of species for the locality. Thus, we cannot assume that species restricted to forest formations are absent from the locality considering only the data we obtained in this study. Only the maintenance of this mosaic of open and forest phytophysiognomies could assure the adequate conservation of this snake assemblage in this ecological station.

Eight individuals of seven species of snakes (Atractus pantostictus, Boa constrictor, Caudisona durissa, Oxyrhopus guibei, Phalotris mertensi, Sibynomorphus mikanii and Thamnodynastes hypoconia) (Table 2) were recorded using the incidental encounter (IE) sampling method. The species Atractus pantostictus, Oxyrhopus guibei and Thamnodynastes hypoconia were found in activity during the night in areas of campo limpo úmido and the other species were active during the day and found in modified areas (Figure 2, Table 2).
Among the 14 species caught in pitfall traps $(\mathrm{N}=41)$, the most abundant were Tantilla melanocephala $(\mathrm{N}=15 ; 36.6 \%)$, Atractus pantostictus $(\mathrm{N}=5 ; 12.2 \%)$, Taeniophallus occipitalis $(\mathrm{N}=4 ; 9.7 \%)$, Liophis almadensis and Oxyrhopus guibei $(\mathrm{N}=3 ; 7.3 \%)$ and Bothrops moojeni and Tricheilostoma koppesi $(\mathrm{N}=2 ; 4.9 \%)$. Only a single individual was found for the other species (Table 2).

Unlike the other two studies conducted in the Cerrado of São Paulo, the most abundant species in the study locality and region $(\mathrm{N}=56)$ was Tantilla melanocephala $(\mathrm{N}=15 ; 26.8 \%)$, followed by Atractus pantostictus $(\mathrm{N}=7 ; 12.5 \%)$, and Taeniophallus occipitalis ( $\mathrm{N}=5 ; 8.9 \%$ ) (Tabela 2). Dalmolin (2000) recorded Caudisona durissa (38.8\%), Xenodon merremi (Wagler, 1824) (8.2\%), and Oxyrhopus guibei $(7.8 \%)$ as the dominant species for the Estação Ecológica de Jataí and surrounding region. Sawaya (2004) verified that for the assemblage at the Estação Ecológica de Itirapina and vicinity, the most abundant species were Caudisona durissa $(13.1 \%)$, Rhinocerophis alternatus (Duméril, Bibron \& Duméril, 1854) (9.9\%) and Bothrops moojeni (6.9\%). Despite the lower richness and abundance of snakes in the Estação Ecológica de Santa Bárbara and region (21 species, $\mathrm{N}=56$ ), the composition of species was very similar to that recorded in the Estação Ecológica de Jataí and municipality of Luiz Antonio (26 species, $\mathrm{N}=219$ ) and in the Estação Ecológica de Itirapina (35 species, $\mathrm{N}=755$ ). 

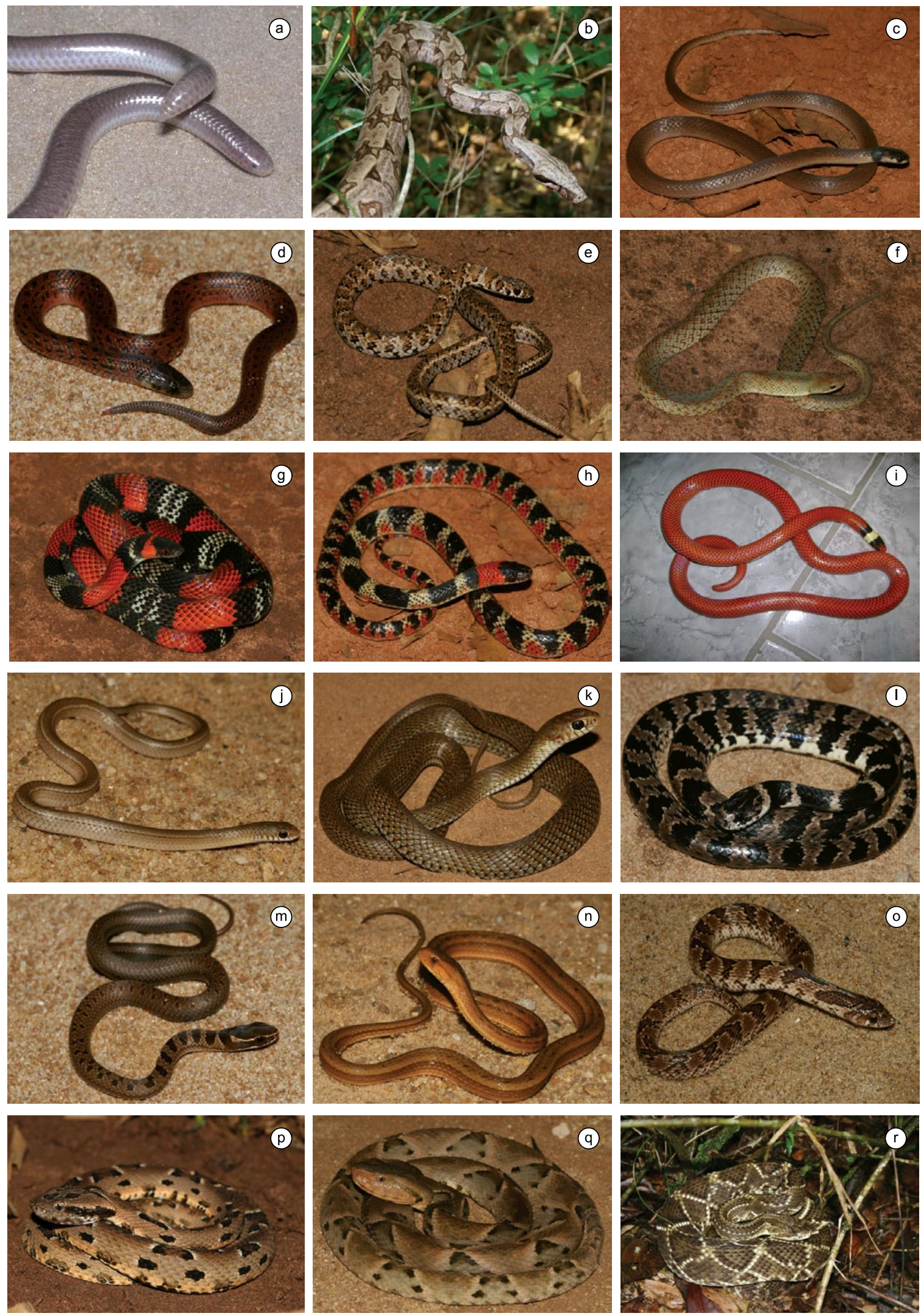

Figure 5. Snake species sampled at the Estação Ecológica de Santa Bárbara, municipality of Águas de Santa Bárbara, state of São Paulo, Brazil. a) Tricheilostoma koppesi; b) Boa constrictor; c) Tantilla melanocephala; d) Atractus pantostictus; e) Liophis almadensis; f) Liophis poecilogyrus; g) Oxyrhopus guibei; h) Oxyrhopus rhombifer; i) Phalotris mertensi; j) Philodryas agassizii; k) Philodryas patagoniensis; 1) Sibynomorphus mikanii; m) Taeniophallus occipitalis; n) Thamnodynastes hypoconia; o) Xenodon nattereri; p) Bothropoides pauloensis; q) Bothrops moojeni; r) Caudisona durissa. Photos: Cybele O. Araujo; Ricardo J. Sawaya (5a); Alexsander Z. Antunes (5i). All individuals were found at the study site except 5a) municipality of Brotas, 5b) municipality of Assis and 5r) municipality of Angatuba. 
The differences in the richness and abundance of species in these three studies may be attributed to differences in the sampling effort and sampling methods used. The apparent abundance of Tantilla melanocephala and Atractus pantostictus in the study site results from the use of pitfall traps as the main sampling method, which favoured the collection of fossorial and cryptozoic species.

Of the snakes found in the Estação Ecológica de Santa Bárbara, the species Philodryas livida, Philodryas agassizii (Figure 5j), and Xenodon nattereri (Figure 5o) are classified as "vulnerable" in the list of endangered species for the State of São Paulo (São Paulo 2008). Philodryas agassizii was observed in an area of cerrado ralo (row 14) and Xenodon nattereri was captured in an area of cerrado típico (row 11) (Figure 2, Table 1, Table 2). These results highlight the need to preserve open formations of this conservation unit. Recent studies indicate that the populations of these species, thought to be restricted to open Cerrado formations (Sawaya et al. 2008, Marques et al. 2006), are decreasing in the state. According to research conducted in the Southeastern region of Cerrado, the cerrado ralo and campo sujo phytophysiognomies are more likely to disappear in the state (Durigan et al. 2003, Durigan \& Ratter 2006). Due to this trend these fragments of Cerrado, albeit reduced, are of extreme importance for the conservation of reptiles in the State of São Paulo (Rossa-Feres et al. 2008).

Recent sampling in the Estação Ecológica de Santa Bárbara (C.O. Araujo, unpublished data) indicate high species richness of the herpetofauna (30 species of amphibians, two species of amphisbaenians, 11 species of lizards), suggesting that this is an area of the Cerrado in São Paulo that is of extreme importance for the conservation of this group of animals. Moreover, this conservation unit is one of the last remaining areas that are protected by law in the state and still house significant areas of open Cerrado formations (Kronka et al. 2005).

\section{Acknowledgements}

We thank Instituto Florestal and FAPESP (2008/54472-2) for financial support; management officer and staff of Estação Ecológica de Santa Bárbara for field assistance; V. Germano for helping during the laboratory work and species identification; G. Durigan for botanical support and very useful suggestions on previous drafts of the manuscript; G. Durigan, E.S. Pinheiro, and N. Guerin to produce the phytophysiognomies map (Figure 2) and S. Serrano Filho and A.M. Luiz for helping to edit the maps (Figure 1).

\section{References}

AB'SÁBER, A.N. 2005. Os domínios de natureza no Brasil: potencialidades paisagísticas. Ateliê Editorial, São Paulo.

BERNARDE, P.S. \& ABE, A.S. 2006. A snake community at Espigão do Oeste, Rondônia, southwestern Amazon, Brazil. S. Am. J. Herpetol. (2):102-113.

BÉRNILS, R.S. 2010. Brazilian reptiles - list of species. Sociedade Brasileira de Herpetologia, São Paulo http://www.sbherpetologia.org.br. (último acesso em: 19/04/2010).

Brasil. Ministério do Planejamento, Orçamento e Gestão. Instituto Brasileiro de Geografia e Estatística - IBGE. 2004. Mapa de Biomas do Brasil: primeira aproximação. Rio de Janeiro.

BRASILEIRO, C.A., SAWAYA, R.J., KIEFER, M.C. \& MARTINS, M. 2005. Amphibians of an open Cerrado fragment in southeastern Brazil. Biota Neotrop. 5(2): http://www.biotaneotropica.org.br/v5n2/ pt/abstract?article+BN00405022005 (último acesso em 15 setembro 2009).

CARVALHO, M.A. \& NOGUEIRA, F. 1998. Serpentes da área urbana de Cuiabá Mato Grosso: aspectos ecológicos e acidentes ofídicos associados. Cad. Saúde Pública Rio de Janeiro. 14(4):753-763.
CECHIN, S.Z. \& MARTINS, M. 2000. Eficiência de armadilhas de queda (Pitfall traps) em amostragens de anfíbios e répteis no Brasil. Rev. Bras. Zool. 17(3):729-749.

CENTENO, F.C., SAWAYA, R.J. \& MARQUES, O.A.V. 2008. Snake assemblage of Ilha de São Sebastião, southeastern Brazil: comparison to mainland. Biota Neotrop. 8(3):63-68, http://www.biotaneotropica. org.br/v8n3/en/abstract?article+bn00608032008. (último acesso em 10 setembro 2009).

CICCHI, P.J.P., SENA, M.A., PECCININI-SEALE, D.M. \& DUARTE, M.R 2007. Serpentes das ilhas costeiras do Estado de São Paulo, Sudeste do Brasil. Biota Neotrop. 7(2):227-240. http://www.biotaneotropica. org.br/v7n2/pt/abstract?article+bn03907022007. (último acesso em: 17/09/2009).

COLLI, G.R., BASTOS, R.P. \& ARAÚJO, A.F.B. 2002. The character and dynamics of the Cerrado herpetofauna. In The cerrados of Brazil: ecology and natural history of a Neotropical Savanna (P.S. Oliveira \& R.J. Marquis, eds.). Columbia University Press, New York, p.223-241.

COLWELL, R.K. 2009. EstimateS: statistical estimation of species richness and shared species from samples. Versão 8.2.0. http://viceroy.eeb.uconn. edu/estimates. (último acesso em: 19 março 2010.)

CONDEZ, T.H., SAWAYA, R.J. \& DIXO, M. 2009. Herpetofauna dos remanescentes de Mata Atlântica da região de Tapiraí e Piedade, SP, sudeste do Brasil. Biota Neotrop. 9(1):157-185.

CORN, P.S. 1994. Straight-line drift-fences and pitfall traps. In Measuring and monitoring biological diversity: standard methods for amphibians (W.R. Heyer, M.A. Donnely, R.W. McDiarmid, L.C. Hayek \& M.S. Foster, eds.). Smithsonian institution Press, Washington and London, p.109-117.

COSTA, G.C., NOGUEIRA, C., MACHADO, R.B. \& COLLI, G.R. 2007. Squamate richness in the Brazilian Cerrado and its environmental-climatic associations. Divers. Distrib. 13(6):714-724.

DALMOLIN, P.C. 2000. Composição e história natural da comunidade de serpentes da Estação Ecológica de Jataí e outras áreas do município de Luiz Antonio, (SP). Dissertação de Mestrado, Universidade Federal de São Carlos, São Carlos.

DIXO, M. \& VERDADE, V.K. 2006. Herpetofauna de serapilheira da Reserva Florestal do Morro Grande, Cotia (SP). Biota Neotrop. 6(2): http://www. biotaneotropica.org.br/v6n2/pt/abstract?article+bn00706022006. (último acesso em 05 setembro 2009).

DOMENICO, E.A. de. 2008. Herpetofauna do Mosaico de Unidades de Conservação do Jacupiranga (SP). Dissertação de Mestrado, Universidade de São Paulo, São Paulo.

DURIGAN, G. \& RATTER, J.A. 2006. Successional changes in Cerrado and Cerrado/forest ecotonal vegetation in Western São Paulo state, Brazil, 1962-2000. Edinburgh J. Bot. 63(1):119-130.

DURIGAN, G., FRANCO, G.A.D.C. \& SIQUEIRA, M.F. 2004. A vegetação dos remanescentes de Cerrado no Estado de São Paulo. In Viabilidade da conservação dos remanescentes de Cerrado no Estado de São Paulo (M.D. Bitencourt \& R.R. Mendonça, orgs.). Annablume, FAPESP, São Paulo, p.29-56.

DURIGAN, G., PINHEIRO, E.S. \& GUERIN, N. (in press). Vegetação. In Plano de Manejo da Estação Ecológica de Santa Bárbara (A.C.G. Melo \& G. Durigan, orgs.). Instituto Florestal, Secretaria do Meio Ambiente do estado de São Paulo, São Paulo.

DURIGAN, G., SIQUEIRA, M.F. \& FRANCO, G.A.D.C. 2007. Threats to the Cerrado remnants of the state of São Paulo, Brazil. Braz. Sci. Agric. 64(4):355-363.

DURIGAN, G., SIQUEIRA, M.F., FRANCO, G.A.D.C., BRIDGEWATER, S. \& RATTER, J.A. 2003. The vegetation of priority areas for Cerrado conservation in São Paulo State, Brazil. Edinburgh J. Bot. 60(2):217-241.

FONSECA, G.A.B., CAVALCANTI, R.B., RYLANDS, A.B. \& PAGLIA, A.P. 2004. Cerrado. In Hotspots revisited: earth's biologically richest and most endangered terrestrial ecoregions (R.A. Mittermeier, P.R. Gil, M. Hoffman, J. Pilgrim, T. Brooks, C.G. Mittermeier, J. Lamoreux \& G.A.B. Fonseca, eds.). CEMEX \& Agrupacion Sierra Madre, Mexico city, p.93-97. 
FONSECA, G.A.B., MITTERMEIER, R.A., CAVALCANTI, R.B. \& MITTERMEIER, C.G. 1999. Brazilian Cerrado. In Hotspots: earth's biologically richest and most endangered terrestrial (R.A. Mittermeier, N. Myers, P.R. Gil \& C.G. Mittermeier, eds.). CEMEX \& Agrupacion Sierra Madre, Mexico city, p.148-159.

FRANÇA, F.G.R. \& ARAÚJO, A.F.B. 2006. The conservation status of snakes in central Brazil. S. Am. J. Herpetol. 1(1):25-36.

GOTELLI, N.J. \& COWELL, R.K. 2001. Quantifying biodiversity: procedures and pitfalls in the measurement and comparison of species richness. Ecol. Lett. 4(4):379-391.

HARTMANN, P.A. 2005. História natural e ecologia de duas taxocenoses de serpentes na Mata Atlântica. Tese de Doutorado, Universidade Estadual Paulista , Rio Claro.

International Union for Conservation of Nature - IUCN. 2009. WCPA Categories System for Protected Areas. http://www.iucn.org/about/ work/programmes/pa/paproducts/wcpacategories. (último acesso em: 15 março 2010).

KLINK, C.A. \& MACHADO, R.B. 2005. Conservation of the Brazilian Cerrado. Conserv. Biol. 19(3):707-713.

KÖPPEN, W. 1948. Climatologia: con un estudio de los climas de la tierra. Fondo de Cultura Econômica, México.

KRONKA, F.J.N., NALON, M.A. \& MATSUKUMA, C.K. 2005. Inventário florestal da vegetação natural do estado de São Paulo. Imprensa Oficial, São Paulo, 200p.

MACHADO, R.B., RAMOS NETO, M.B., PEREIRA, P.G.P., CALDAS, E.F., GONÇALVES, D.A., SANTOS, N.S., TABOR, K. \& STEININGER, M. 2004. Estimativas de perda da área do Cerrado brasileiro. Conservation International do Brasil, Brasília.

MARQUES, O.A.V. 1998. Composição faunística, história natural e ecologia de serpentes da Mata Atlântica na região da Estação Ecológica JuréiaItatins, São Paulo, SP. Tese de Doutorado, Universidade de São Paulo, São Paulo.

MARQUES, O.A.V., SAWAYA, R.J., STENDER-OLIVEIRA, F. \& FRANÇA, F.G.R. 2006. Ecology of the colubrid snake Pseudablabes agassizii in southeastern South America. Herpetol. J. 16(1):37-45.

MARTINS, M. 1994. História Natural e Ecologia de uma taxocenose de serpentes em Mata Atlântica Primária na região de Manaus, Amazônia Central, Brasil. Tese de Doutorado, Universidade Estadual de Campinas, Campinas.

MITTERMEIER, R.A., GIL, P.R., HOFFMAN, M., PILGRIM, J., BROOKS, T., MITTERMEIER, C.G., LAMOREUX, J. \& FONSECA, G.A.B. 2004. Hotspots revisited: earth's biologically richest and most endangered terrestrial ecoregions. CEMEX \& Agrupacion Sierra Madre, Mexico city.

MORAES, R.A., SAWAYA, R.J. \& BARRELA, W. 2007. Composição e diversidade de anfíbios anuros em dois ambientes de Mata Atlântica no Parque Estadual Carlos Botelho, São Paulo, sudeste do Brasil. Biota Neotrop. 7(2):1-10 http://www.biotaneotropica.org.br/v7n2/pt/ abstract?article+bn00307022007. (último acesso em: 24 março 2010).

MYERS, N., MITTERMEIER, R.A., MITTERMEIER, C.G., FONSECA, G.A.B. \& KENT, J. 2000. Biodiversity hotspots for conservation priorities. Nature 403:853-858.

NOGUEIRA, C., COLLI, G.R. \& MARTINS, M. 2009. Local richness and distribution of the lizard fauna in natural habitat mosaics of the Brazilian Cerrado. Austral Ecol. 34:83-96.

OLIVEIRA-FILHO, A.T. \& RATTER, J.A. 2002. Vegetation physiognomies and woody flora of the Cerrado Biome. In The cerrados of Brazil: ecology and natural history of a Neotropical Savanna (P.S. Oliveira \& R.J. Marquis, eds.). Columbia University Press, New York, p.91-120.
RATTER, J.A., RIBEIRO, J.F. \& BRIDGEWATER, S. 1997. The Brazilian Cerrado vegetation and threats to its biodiversity. Ann. Bot. 80:223-230.

RIBEIRO, J.F. \& WALTER, B.M.T. 2008. As principais fitofisionomias do Bioma Cerrado. In Cerrado: ecologia e flora (S.M. Sano, S.P. Almeida \& J.F. Ribeiro, eds.). Embrapa, Cerrados , Planaltina, p.153-212.

ROCHA, C.F.D., BERGALLO, H.G., CONDE, C.F.V., BITTENCOURT, E.B. \& SANTOS, H.C. 2008. Richness, abundance, and mass in snake assemblages from two Atlantic Rainforest sites (Ilha do Cardoso, São Paulo) with differences in environmental productivity. Biota Neotrop. 8(3):117-122.

ROSSA-FERES, D.C., MARTINS, M., MARQUES, O.A.V., MARTINS, I.A., SAWAYA, R.J. \& HADDAD, C.F.B. 2008. Herpetofauna. In Diretrizes para a conservação e restauração da biodiversidade no estado de São Paulo (R.R. Rodrigues \& V.LR. Bononi, eds.). Governo do estado de São Paulo, São Paulo, p.82-94.

São Paulo (Estado). 1997. Cerrado: Bases para a conservação e uso sustentável das áreas de Cerrado do Estado de São Paulo. SEMA, São Paulo.

São Paulo (Estado). 2008. Decreto Estadual n ${ }^{\circ} 53.494$, de 02 de outubro de 2008. http://www.imprensaoficial.com.br. (último acesso em 05 março 2009).

SAWAYA, R.J. 2004. História natural e ecologia das serpentes de Cerrado da região de Itirapina, SP. Tese de Doutorado, Universidade Estadual de Campinas, Campinas.

SAWAYA, R.J., MARQUES, O.A.V. \& MARTINS, M. 2008. Composition and natural history of a Cerrado snake assemblage at Itirapina, São Paulo State, southeastern Brazil. Biota Neotrop. 8(2):129-151.

SAZIMA, I. \& HADDAD, C.F.B. 1992. Répteis da Serra do Japi: notas sobre história natural. In História natural da Serra do Japi: ecologia e preservação de uma área florestal no sudeste do Brasil. (P. Morellato, org.). Editora da UNICAMP, Campinas, p.212-235.

SAZIMA, I. \& MANZANI, P.R. 1995. As cobras que vivem numa reserva florestal urbana. In Ecologia e preservação de uma floresta tropical urbana: reserva de Santa Genebra (L.P.C. Morellato \& H.F. Leitão-Filho, eds.). Universidade Estadual de Campinas, Campinas, p.78-82.

SAZIMA, I. 2001. Répteis. In Intervales: fundação para a conservação e produção florestal do estado de São Paulo (C. Leonel, ed.). Fundação Florestal, São Paulo, p.148-158.

SENA, M.A. 2007. Levantamento da fauna e estudo cromossômico de algumas espécies de Reptilia, Squamata, do município de Cananéia, SP. Dissertação de Mestrado, Universidade de São Paulo, São Paulo.

SETZER, J. 1966. Atlas climático e ecológico do estado de São Paulo. Comissão Interestadual da Bacia do Paraná, Uruguai e Centrais Elétricas de São Paulo, São Paulo.

STRÜSSMANN, C. \& SAZIMA, I. 1993. The snake assemblage of the Pantanal at Poconé westernBrazil: faunal composition and ecological summary. Stud. Neotrop. Fauna Environ. 28(3):157-168.

STRÜSSMANN, C. 2000. Herpetofauna. In Fauna silvestre da região do Rio Manso, MT (C.J.R. Alho, ed.). MMA, IBAMA, ELETRONORTE, Brasília, p.153-189.

VANZOLINI, P.E. 1948. Notas sobre os ofídios e lagartos da Cachoeira de Emas, no município de Pirassununga, Estado de São Paulo. Rev. Bras. Biol. 8:377-400.

VITT, L.J. \& VANGILDER, L.D. 1983. Ecology of a snake community in northeastern Brazil. Amphib. Reptil. 4(2-4):273-296.

Received 26/10/09

Revised 20/04/10

Accpeted 26/04/10 


\section{Appendix 1}

Appendix 1. Snake species collected at the Estação Ecológica de Santa Bárbara and municipality of Águas de Santa Bárbara, state of São Paulo, Brazil and deposited in the Coleção Herpetológica do Instituto Butantan (IBSP) and Museu de Zoologia da Universidade de São Paulo (MZUSP).

Atractus pantostictus (MZUSP 14985, IBSP 77321-77323); Bothrops moojeni (IBSP 77315-77316); Bothropoides pauloensis (IBSP 77314); Caudisona durissa (IBSP 77261); Liophis almadensis (IBSP 77312-77313, 77326); Liophis poecilogyrus (IBSP 77311); Liophis reginae (IBSP 56962); Micrurus frontalis (IBSP 46342); Oxyrhopus guibei (IBSP 77318-77320); Oxyrhopus rhombifer (IBSP 77307); Philodryas agassizii (IBSP 77301); Philodryas livida (IBSP 40953); Philodryas patagoniensis (IBSP 77324); Sibynomorphus mikanii (MZUSP 14986, IBSP 77317); Taeniophallus occipitalis (IBSP 53729, 77298-77299, 77327-77328); Tantilla melanocephala (IBSP 77302-77306); Thamnodynastes hypoconia (IBSP 77308-77310); Tricheilostoma koppesi (MZUSP 14976, IBSP 77300); Xenodon nattereri (IBSP 77325). 